\title{
Sandbar Formation in the Mesjid River Estuary, Rupat Strait, Riau Province, Indonesia
}

\author{
Rifardi and Yeeri Badrun
}

Received: 08062016 / Accepted: 2706 2016 / Published online: 31122017

(c) 2017 Faculty of Geography UGM and The Indonesian Geographers Association

\begin{abstract}
At the aim to clarify the relationship between the sandbar formation and lithogeneous sediment discharges, the sedimentological aspects of the Mesjid River Estuary are revealed by various analysis. The samples of bottom surface sediments and the suspended sediment were collected at 50 stations in the estuary using grab and van dorm samplers. Oceanographic observation were also carried out at the stations. The Mesjid River Estuary receives lithogeneous sediments mainly from the Mesjid River's drainage areas which play important role on the formation of sandbar which is shown by a belt-like area (0.5-1.0 m depth) in the area off the river mouth. The sandbar might become a sandbank in 20 to 40 years later. High suspended sediment up to $354.61 \mathrm{mg} / \mathrm{l}$ indicates the river mouth receives lithogeneous sediments. Total of 926 ton/day of the sediments supplied by the river are deposited $0.024 \mathrm{~m} /$ year into the area.
\end{abstract}

Keywords:Bottom surface sediments, Bottom character, Suspended sediment, Sediment discharge, Sedimentation rates.

\begin{abstract}
Abstrak Berbagai analisis aspek-aspek sedimentologi dilakukan untuk mengklarifikasi hubungan antara pembentukan sandbar dan pemasukan sedimen lithogeneous di daerah Estuaria Sungai Mesjid. Sampel sedimen dasar dan sedimen tersuspensi diambil dari 50 stasiun tersebar di estuaria tersebut menggunakan grab dan van dorm sampler. Parameter oceanografi juga diukur pada setiap stasiun. Daerah Estuaria Sungai Mesjid menerima suplai sedimen lithogeneous dominan dari Sungai Mesjid yang berasal dari daerah tangkapannya, menjadi sumber utama pembentukan sandbar di daerah depan mulut sungai berbentuk seperti sabuk. Daerah seperti sabuk ini merupakan sandbar dalam proses pembentukan, memiliki batimetri paling dangkal 0,5-1,0 m dan diduga akan menjadi sandbank dalam kurun waktu 20-40 tahun. Suplai sedimen lithogeneous ditunjukkan oleh nilai sedimen tersuspensi pada mulut sungai sangat tinggi mencapai 354,61 mg/l. 926 ton/hari sedimen tersebut disuplai oleh sungai ini dan diendapkan dengan kecepatan 0,024 m/tahun di daerah depan mulut sungai.
\end{abstract}

Kata kunci: Sedimen permukaan dasar, Sedimen tersuspensi, Pemasukan sedimen, Kecepatan pengendapan, Karakter dasar perairan

\section{Introduction}

An estuary is a partially enclosed coastal body of water that is either permanently or periodically open to the sea and which receives at least periodic discharge from a river(s), and thus, while its salinity is typically less than that of natural sea water and varies temporally and along its length, it can become hypersaline in regions when evaporative water loss is high and freshwater and tidal inputs are negligible [Potter at al., 2010]. The estuary serves as a temporary storage reservoir for materials contributed from the watershed [Gebert et al., 2013] Estuary may periodically receive large amounts of terrigenous sediment from the whole catchment during heavy rain and that extreme erosion events caused by intense local rain storms may produce flooding and massive sediment deposition from relatively small parts of the catchment [Gibbs and Bremner, 2008].

The Mesjid River Estuary is located in the eastern

Rifardi and Yeeri Badrun

Department of Marine Sciences, Faculty of Fisheries and Marine

Sciences, Riau University, Pekanbaru, Riau, Indonesia Department of Biology, Faculty of Mathemathic and Natural Sciences, Muhammadyah University, Pekanbaru, Riau, Indonesia Correspondent email:fardi64@yahoo.co.id coast of central Sumatera Island, Riau Province, Indonesia. The estuary is connected to Malacca Strait by the Rupat Strait. The Rupat Strait is characterized by high sedimentation rates due to sediment discharged by current system and rivers [Rifardi, 2001]. One of the rivers is Mesjid River which has rather large drainage area flow into the strait through the estuary. The drainage area has been rapidly developed and became the center of community residents, industries, and of agriculture. Consequently, the river receives sediments from erosion of the drainage area as shown by high concentration of suspended sediment.

Since three decades ago, the estuary and its environs have become one of the most intensively studied area in relation to water quality, marine biology, and marine sediments. Significant studies in ecological and oceanographical aspects of the estuary and its environs have been carried out by Alkhatib at al. [2007]; Amin et al. [2007]; Amin et al. [2008]; Rifardi [2008]; Badrun [2008]; Amin et al. [2009]; Purba and Khan [2010]; Nedi et al. [2010]; Musrifin [2011]; Wöstmann and Liebezeit [2012]; Rifardi and Syahrul [2013]; Rifardi et al. [2015]; Rifardi [2015]; Syahminan 


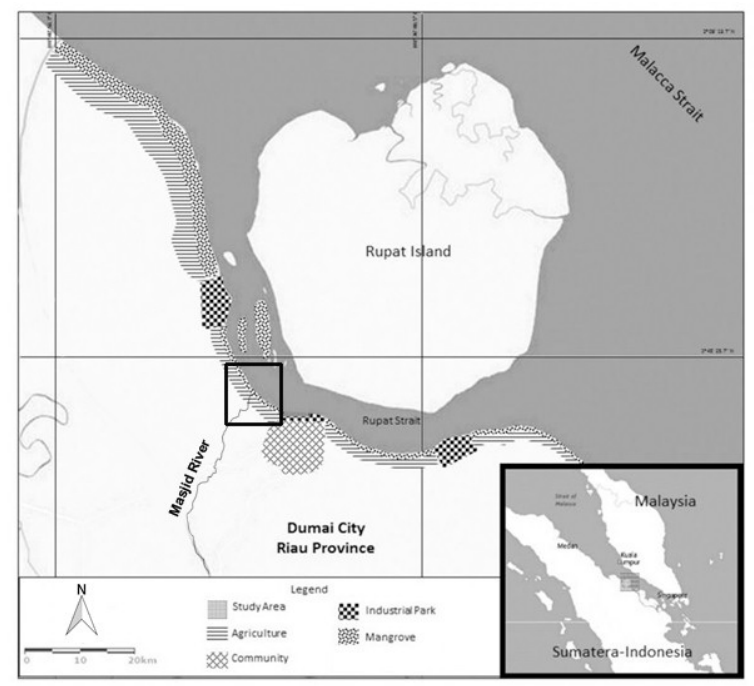

Figure 1. Index map of the study area

at al. [2015]; Merian at al. [2016]; and Putra et al. [2017]. However, there is no any study concerning to the sediment discharge and depositional rates.

The objective of this study is to clarify the relationship between the formation of sandbar and lithogeneous sediments discharge, based on the sedimentary environment featured by sediment distributions and oceanographic observation, and analyses of sediments transported from the Mesjid River and the sedimentation rates in the estuary.

Physiographic setting. The Rupat Strait, is separated from Malacca Strait by Rupat Island, is located on the eastern coast of Sumatera Island, Riau Province. The Rupat Strait, located between Sumatera Island and Malacca Strait, it is elongated and has northward, southward-openings with a length of about $88 \mathrm{~km}$ from north to south and a width of about $8 \mathrm{~km}$. Th e outlets are leading to Malacca Strait (Figure 1).

The area studied is restricted to the Mesjid River Estuary and its surrounding area in the Rupat Strait, located within the lines of $01^{\circ} 43^{\prime} 5.99^{\prime \prime} \mathrm{N}$ and $01^{\circ} 43^{\prime} 31.58^{\prime \prime} \mathrm{N}$ Lat. and $101^{\circ} 23^{\prime} 8.33^{\prime \prime} \mathrm{E}$ and $101^{\circ} 23^{\prime} 26.20^{\prime \prime} \mathrm{E}$ Long. (Figure 2). The area studied has a rather flat bottom topography and is influenced by water masses from the Mesjid River and Malacca Strait by tidal currents and anthropogenic activities, and the bottom topography gets gradually deeper northeastwards. The river with rather large drainage areas, flows into estuary of the area. The coastal zone of the estuary is characterized by mangrove vegetation, such as Avicennia sp, Rhizopora sp. In addition, the remains of mangrove vegetation can be found along the coastal line of the estuary which is under the influence of longshore currents [Rifardi, 2001].

\section{The Methods}

The samples of bottom surface sediment and the suspended sediment were collected from 50 stations in the Mesjid River Estuary and its surrounding area, from 0.41 to $21.42 \mathrm{~m}$ depths,in August to November

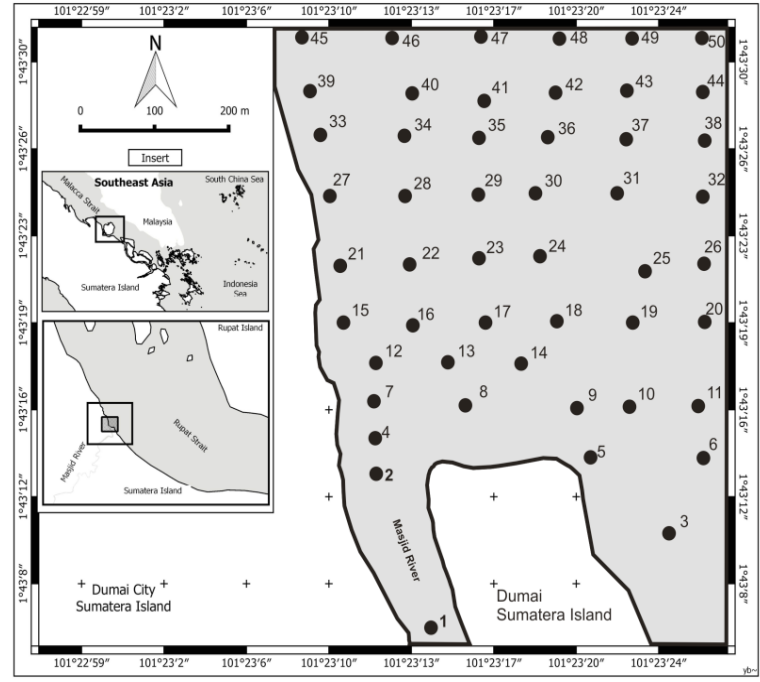

Figure 2. The study area showing sampling stations

2015. The positions of the sampling stations were determined by using the Global Positioning System (Figure 2). Oceanographic observation was also carried out to measure velocity and direction of tidal current, depth and salinity at 50 stations. All bottom samples were collected by using grab sampler. The samples were used for analysis of mechanical grain size. The gravel and sand proportions were determined by sieving and were weighed oven dried (Rifardi et al.,1998). The settling tube method was utilized to determine the mud proportion. The graphical method was used to calculate the mean diameter (Mzø), sorting coefficient $\left(\hat{\mathrm{O}}_{\mathrm{i}}\right)$ and skewness $\left(\mathrm{Sk}_{\mathrm{i}}\right)$ of the sediments. The textural proportions of gravel, sand and mud were plotted on Shepard's triangle.

To determine the accumulated sediments during the ebb tide, sediment traps were place in 4 stations (Stn. 7, 12, 13 and 15). The concentrations of suspended sediment at three different depths (surface, middle and bottom) were measured at Station 2. Beside the suspended sediment, other parameters namely current velocity and the width of the Mesjid River mouth were also measured to determine water discharge during the ebb tide.

Suspended sediment concentration $(\mathrm{mg} / \mathrm{l})$ and water discharge $(\mathrm{m} 3 / \mathrm{s})$ of the river were used to determine total amount oflithogeneous sediments (ton/year) discharged by the Mesjid River into the estuary after converting the unit of liter (l) to $\mathrm{dm}^{3}$ and of second (s) to year.

Accumulated sediments in sediment traps were calculated based on total amount of sediments (gram and/or $\mathrm{ml}$ ) trapped in the sediment trap $\left(\mathrm{m}^{2}\right)$ in period of time (day), as proposed by modified by Rifardi [2012]. The accumulated sediments were utilized to estimate sedimentation rates ( $\mathrm{m} /$ year) after converting the unit of $\mathrm{ml}$ to $\mathrm{m}^{3}$ and of day to year.

\section{Result and Discussion}

The results of mechanical analysis of the 50 bottom sediment samples and of oceanographic observation are shown in Table 1. The distributions 
Indonesian Journal of Geography, Vol. 49 No. 1, June 2017: 65 - 72

Table 1. Results of mechanical analysis of the bottom sediments and oceanographic observation (SS = suspended sediment)

\begin{tabular}{|c|c|c|c|c|c|c|c|c|c|c|c|}
\hline Station & Longitude & Latitude & Sand (\%) & $\begin{array}{l}\text { Mud } \\
(\%)\end{array}$ & $\begin{array}{l}\mathrm{Mz} \\
(\varpi)\end{array}$ & $\begin{array}{l}\text { Ó凶 } \\
(ø)\end{array}$ & Sk囚 & $\begin{array}{l}\text { Bottom } \\
\text { Character }\end{array}$ & $\begin{array}{l}\text { Depth } \\
\text { (m) }\end{array}$ & $\begin{array}{l}\text { Salinity } \\
(\%)\end{array}$ & $\begin{array}{l}\text { SS } \\
(\mathrm{mg} / \mathrm{l})\end{array}$ \\
\hline 1 & $101^{\circ} 23^{\prime} 14.4070^{\prime \prime} \mathrm{E}$ & $1^{\circ} 43^{\prime} 5.9887^{\prime \prime} \mathrm{N}$ & 69.56 & 30.44 & 3.40 & 3.69 & 0.99 & Muddy Sand & -3.60 & 10.00 & 185.17 \\
\hline 2 & $101^{\circ} 23^{\prime} 11.5146^{\prime \prime} \mathrm{E}$ & $1^{\circ} 43^{\prime} 12.9724^{\prime \prime} \mathrm{N}$ & 47.83 & 52.17 & 5.00 & 0.76 & 0.91 & Sandy Mud & -3.19 & 12.47 & 354.61 \\
\hline 3 & $101^{\circ} 23^{\prime} 24.5415^{\prime \prime} \mathrm{E}$ & $1^{\circ} 43^{\prime} 10.5921^{\prime \prime} \mathrm{N}$ & 25.35 & 74.65 & 6.00 & 0.63 & 1.01 & Sandy Mud & -5.24 & 30.60 & 34.76 \\
\hline 4 & $101^{\circ} 23^{\prime} 11.5581^{\prime \prime} \mathrm{E}$ & $1^{\circ} 43^{\prime} 14.4490^{\prime \prime} \mathrm{N}$ & 40.00 & 60.00 & 6.00 & 0.50 & 0.86 & Sandy Mud & -2.60 & 13.09 & 37.40 \\
\hline 5 & $101^{\circ} 23^{\prime} 21.2148^{\prime \prime} \mathrm{E}$ & $1^{\circ} 43^{\prime} 13.7038^{\prime \prime} \mathrm{N}$ & 30.00 & 70.00 & 6.00 & 0.14 & 0.99 & Sandy Mud & -4.87 & 27.98 & 136.49 \\
\hline 6 & $101^{\circ} 23^{\prime} 26.0560^{\prime \prime} \mathrm{E}$ & $1^{\circ} 43^{\prime} 13.7038^{\prime \prime} \mathrm{N}$ & 23.04 & 76.96 & 6.06 & 0.10 & 0.54 & Mud & -12.29 & 33.06 & 141.23 \\
\hline 7 & $101^{\circ} 23^{\prime} 11.5581^{\prime \prime} \mathrm{E}$ & $1^{\circ} 43^{\prime} 15.9936^{\prime \prime} \mathrm{N}$ & 52.55 & 47.45 & 5.00 & 0.61 & 0.80 & Muddy Sand & -1.42 & 15.02 & 38.58 \\
\hline 8 & $101^{\circ} 23^{\prime} 15.5957^{\prime \prime} \mathrm{E}$ & $1^{\circ} 43^{\prime} 15.8205^{\prime \prime} \mathrm{N}$ & 42.91 & 57.06 & 5.21 & 0.23 & 0.99 & Sandy Mud & -5.79 & 18.82 & 94.36 \\
\hline 9 & $101^{\circ} 23^{\prime} 20.5610^{\prime \prime} \mathrm{E}$ & $1^{\circ} 43^{\prime} 15.8701^{\prime \prime} \mathrm{N}$ & 47.06 & 54.00 & 6.00 & 0.45 & 0.99 & Sandy Mud & -15.15 & 28.62 & 228.20 \\
\hline 10 & $101^{\circ} 23^{\prime} 22.8572^{\prime \prime} \mathrm{E}$ & $1^{\circ} 43^{\prime} 15.8312^{\prime \prime} \mathrm{N}$ & 30.29 & 69.63 & 6.00 & 0.39 & 0.98 & Sandy Mud & -15.47 & 30.24 & 227.39 \\
\hline 11 & $101^{\circ} 23^{\prime} 26.0361^{\prime \prime} \mathrm{E}$ & $1^{\circ} 43^{\prime} 15.8867^{\prime \prime} \mathrm{N}$ & 67.92 & 76.96 & 6.10 & 0.16 & 0.54 & Mud & -15.13 & 32.99 & 213.81 \\
\hline 12 & $101^{\circ} 23^{\prime} 11.6359^{\prime \prime} \mathrm{E}$ & $1^{\circ} 43^{\prime} 17.6596^{\prime \prime} \mathrm{N}$ & 63.83 & 36.28 & 4.74 & 0.82 & 0.97 & Muddy Sand & -0.54 & 17.18 & 39.46 \\
\hline 13 & $101^{\circ} 23^{\prime} 14.8137^{\prime \prime} \mathrm{E}$ & $1^{\circ} 43^{\prime} 17.6761^{\prime \prime} \mathrm{N}$ & 67.10 & 32.90 & 3.43 & 0.71 & 0.99 & Muddy Sand & -0.54 & 20.10 & 39.62 \\
\hline 14 & $101^{\circ} 23^{\prime} 18.0246^{\prime \prime} \mathrm{E}$ & $1^{\circ} 43^{\prime} 17.6927^{\prime \prime} \mathrm{N}$ & 48.64 & 51.40 & 5.49 & 0.71 & 0.99 & Sandy Mud & -13.32 & 24.91 & 109.99 \\
\hline 15 & $101^{\circ} 23^{\prime} 9.9849^{\prime \prime} \mathrm{E}$ & $1^{\circ} 43^{\prime} 19.3084^{\prime \prime} \mathrm{N}$ & 52.01 & 47.99 & 5.02 & 0.79 & 0.59 & Muddy Sand & -1.22 & 17.84 & 53.33 \\
\hline 16 & $101^{\circ} 23^{\prime} 13.2620^{\prime \prime} \mathrm{E}$ & $1^{\circ} 43^{\prime} 19.3250^{\prime \prime} \mathrm{N}$ & 44.90 & 55.09 & 4.52 & 0.90 & 0.99 & Sandy Mud & -15.95 & 20.68 & 67.88 \\
\hline 17 & $101^{\circ} 23^{\prime} 16.4564^{\prime \prime} \mathrm{E}$ & $1^{\circ} 43^{\prime} 19.3912^{\prime \prime} \mathrm{N}$ & 43.29 & 56.72 & 5.61 & 0.87 & 0.99 & Sandy Mud & -13.50 & 23.98 & 70.31 \\
\hline 18 & $101^{\circ} 23^{\prime} 19.6673^{\prime \prime} \mathrm{E}$ & $1^{\circ} 43^{\prime} 19.4077^{\prime \prime} \mathrm{N}$ & 34.71 & 65.29 & 6.82 & 0.84 & 0.99 & Sandy Mud & -16.04 & 29.03 & 136.47 \\
\hline 19 & $101^{\circ} 23^{\prime} 22.9159^{\prime \prime} \mathrm{E}$ & $1^{\circ} 43^{\prime} 19.4081^{\prime \prime} \mathrm{N}$ & 37.30 & 71.34 & 6.00 & 0.52 & 0.93 & Sandy Mud & -16.25 & 31.02 & 191.22 \\
\hline 20 & $101^{\circ} 23^{\prime} 26.1981^{\prime \prime} \mathrm{E}$ & $1^{\circ} 43^{\prime} 19.4236^{\prime \prime} \mathrm{N}$ & 22.61 & 77.39 & 6.20 & 0.28 & 0.51 & Mud & -16.84 & 33.19 & 191.98 \\
\hline 21 & $101^{\circ} 23^{\prime} 9.9532^{\prime \prime} \mathrm{E}$ & $1^{\circ} 43^{\prime} 21.7227^{\prime \prime} \mathrm{N}$ & 33.39 & 66.61 & 6.98 & 0.52 & 0.53 & Sandy Mud & -1.76 & 19.54 & 38.24 \\
\hline 22 & $101^{\circ} 23^{\prime} 13.1261^{\prime \prime} \mathrm{E}$ & $1^{\circ} 43^{\prime} 21.7723^{\prime \prime} \mathrm{N}$ & 30.62 & 69.38 & 6.87 & 0.65 & 0.93 & Sandy Mud & -15.40 & 21.60 & 71.09 \\
\hline 23 & $101^{\circ} 23^{\prime} 16.1903^{\prime \prime} \mathrm{E}$ & $1^{\circ} 43^{\prime} 22.1035^{\prime \prime} \mathrm{N}$ & 30.30 & 69.70 & 7.38 & 0.65 & 0.99 & Sandy Mud & -17.37 & 26.20 & 232.64 \\
\hline 24 & $101^{\circ} 23^{\prime} 19.0120^{\prime \prime} \mathrm{E}$ & $1^{\circ} 43^{\prime} 22.1445^{\prime \prime} \mathrm{N}$ & 30.00 & 70.00 & 7.13 & 0.55 & 0.95 & Sandy Mud & -17.89 & 29.67 & 232.11 \\
\hline 25 & $101^{\circ} 23^{\prime} 23.5492^{\prime \prime} \mathrm{E}$ & $1^{\circ} 43^{\prime} 21.4722^{\prime \prime} \mathrm{N}$ & 47.12 & 73.14 & 3.41 & 0.30 & 0.85 & Sandy Mud & -17.55 & 31.64 & 182.45 \\
\hline 26 & $101^{\circ} 23^{\prime} 26.1567^{\prime \prime} \mathrm{E}$ & $1^{\circ} 43^{\prime} 21.7961^{\prime \prime} \mathrm{N}$ & 70.05 & 77.36 & 6.19 & 0.14 & 0.51 & Mud & -17.69 & 33.08 & 182.31 \\
\hline 27 & $101^{\circ} 23^{\prime} 9.5885^{\prime \prime} \mathrm{E}$ & $1^{\circ} 43^{\prime} 24.6723^{\prime \prime} \mathrm{N}$ & 30.27 & 69.72 & 6.57 & 0.13 & 0.58 & Sandy Mud & -2.47 & 20.00 & 56.88 \\
\hline 28 & $101^{\circ} 23^{\prime} 12.8294^{\prime \prime} \mathrm{E}$ & $1^{\circ} 43^{\prime} 24.5896^{\prime \prime} \mathrm{N}$ & 32.22 & 67.78 & 6.50 & 0.15 & 1.00 & Sandy Mud & -12.46 & 23.61 & 78.66 \\
\hline 29 & $101^{\circ} 23^{\prime} 16.0702^{\prime \prime} \mathrm{E}$ & $1^{\circ} 43^{\prime} 24.6723^{\prime \prime} \mathrm{N}$ & 30.00 & 70.00 & 6.31 & 0.10 & 0.99 & Sandy Mud & -17.58 & 27.80 & 124.69 \\
\hline 30 & $101^{\circ} 23^{\prime} 18.6880^{\prime \prime} \mathrm{E}$ & $1^{\circ} 43^{\prime} 24.7528^{\prime \prime} \mathrm{N}$ & 30.00 & 70.00 & 3.42 & 0.11 & 0.90 & Sandy Mud & -18.98 & 30.20 & 167.39 \\
\hline 31 & $101^{\circ} 23^{\prime} 22.2529^{\prime \prime} \mathrm{E}$ & $1^{\circ} 43^{\prime} 24.7528^{\prime \prime} \mathrm{N}$ & 40.84 & 71.99 & 6.13 & 0.10 & 0.76 & Sandy Mud & -19.87 & 31.68 & 180.13 \\
\hline 32 & $101^{\circ} 23^{\prime} 26.1419^{\prime \prime} \mathrm{E}$ & $1^{\circ} 43^{\prime} 24.6183^{\prime \prime} \mathrm{N}$ & 70.68 & 77.48 & 6.36 & 0.10 & 0.51 & Mud & -18.86 & 33.06 & 181.14 \\
\hline 33 & $101^{\circ} 23^{\prime} 9.1479^{\prime \prime} \mathrm{E}$ & $1^{\circ} 43^{\prime} 27.1751^{\prime \prime} \mathrm{N}$ & 47.10 & 52.90 & 5.65 & 0.66 & 1.50 & Sandy Mud & -4.72 & 23.83 & 94.84 \\
\hline 34 & $101^{\circ} 23^{\prime} 12.9100^{\prime \prime} \mathrm{E}$ & $1^{\circ} 43^{\prime} 27.0499^{\prime \prime} \mathrm{N}$ & 46.74 & 53.25 & 3.40 & 0.66 & 0.99 & Sandy Mud & -15.49 & 26.89 & 84.66 \\
\hline 35 & $101^{\circ} 23^{\prime} 16.0817^{\prime \prime} \mathrm{E}$ & $1^{\circ} 43^{\prime} 26.9954^{\prime \prime} \mathrm{N}$ & 40.46 & 59.54 & 6.00 & 0.57 & 0.96 & Sandy Mud & -17.64 & 30.14 & 115.89 \\
\hline 36 & $101^{\circ} 23^{\prime} 19.3484^{\prime \prime} \mathrm{E}$ & $1^{\circ} 43^{\prime} 26.9954^{\prime \prime} \mathrm{N}$ & 30.00 & 70.00 & 6.15 & 0.33 & 0.82 & Sandy Mud & -19.92 & 31.05 & 165.95 \\
\hline 37 & $101^{\circ} 23^{\prime} 22.6325^{\prime \prime} \mathrm{E}$ & $1^{\circ} 43^{\prime} 26.9672^{\prime \prime} \mathrm{N}$ & 36.74 & 71.24 & 6.38 & 0.10 & 0.69 & Sandy Mud & -20.76 & 32.15 & 169.93 \\
\hline 38 & $101^{\circ} 23^{\prime} 26.1419^{\prime \prime} \mathrm{E}$ & $1^{\circ} 43^{\prime} 26.9846^{\prime \prime} \mathrm{N}$ & 23.87 & 76.13 & 6.59 & 0.10 & 0.51 & Mud & -18.61 & 33.55 & 171.63 \\
\hline 39 & $101^{\circ} 23^{\prime} 8.6414^{\prime \prime} \mathrm{E}$ & $1^{\circ} 43^{\prime} 29.0013^{\prime \prime} \mathrm{N}$ & 57.48 & 41.79 & 5.93 & 0.87 & 1.99 & Muddy Sand & -4.99 & 28.30 & 108.34 \\
\hline 40 & $101^{\circ} 23^{\prime} 13.1397^{\prime \prime} \mathrm{E}$ & $1^{\circ} 43^{\prime} 28.8713^{\prime \prime} \mathrm{N}$ & 58.45 & 40.72 & 5.52 & 0.88 & 1.07 & Muddy Sand & -15.42 & 30.11 & 96.22 \\
\hline 41 & $101^{\circ} 23^{\prime} 16.4342^{\prime \prime} \mathrm{E}$ & $1^{\circ} 43^{\prime} 28.7534^{\prime \prime} \mathrm{N}$ & 45.29 & 54.72 & 6.20 & 0.62 & 0.90 & Sandy Mud & -17.81 & 30.91 & 114.21 \\
\hline 42 & $101^{\circ} 23^{\prime} 19.6751^{\prime \prime} \mathrm{E}$ & $1^{\circ} 43^{\prime} 28.7948 " \mathrm{~N}$ & 33.59 & 66.35 & 6.43 & 0.34 & 0.77 & Sandy Mud & -19.86 & 31.74 & 159.82 \\
\hline 43 & $101^{\circ} 23^{\prime} 22.8158^{\prime \prime} \mathrm{E}$ & $1^{\circ} 43^{\prime} 28.8713^{\prime \prime} \mathrm{N}$ & 30.84 & 69.16 & 6.59 & 0.10 & 0.64 & Sandy Mud & -20.09 & 32.65 & 160.17 \\
\hline 44 & $101^{\circ} 23^{\prime} 26.1532^{\prime \prime} \mathrm{E}$ & $1^{\circ} 43^{\prime} 28.7948^{\prime \prime} \mathrm{N}$ & 34.15 & 70.76 & 6.78 & 0.10 & 0.50 & Sandy Mud & -18.83 & 33.93 & 161.19 \\
\hline 45 & $101^{\circ} 23^{\prime} 8.3321^{\prime \prime} \mathrm{E}$ & $1^{\circ} 43^{\prime} 31.4826^{\prime \prime} \mathrm{N}$ & 49.87 & 50.13 & 6.52 & 0.76 & 0.88 & Sandy Mud & -5.49 & 34.13 & 126.73 \\
\hline 46 & $101^{\circ} 23^{\prime} 12.1685^{\prime \prime} \mathrm{E}$ & $1^{\circ} 43^{\prime} 31.5626^{\prime \prime} \mathrm{N}$ & 49.63 & 50.37 & 6.48 & 0.63 & 0.64 & Sandy Mud & -14.69 & 34.24 & 114.57 \\
\hline 47 & $101^{\circ} 23^{\prime} 16.1795^{\prime \prime} \mathrm{E}$ & $1^{\circ} 43^{\prime} 31.5760^{\prime \prime} \mathrm{N}$ & 46.90 & 53.11 & 6.63 & 0.41 & 0.63 & Sandy Mud & -17.81 & 34.25 & 112.79 \\
\hline 48 & $101^{\circ} 23^{\prime} 19.6856^{\prime \prime} \mathrm{E}$ & $1^{\circ} 43^{\prime} 31.5536^{\prime \prime} \mathrm{N}$ & 39.26 & 60.71 & 6.87 & 0.34 & 0.64 & Sandy Mud & -18.31 & 34.21 & 147.83 \\
\hline 49 & $101^{\circ} 23^{\prime} 22.8985^{\prime \prime} \mathrm{E}$ & $1^{\circ} 43^{\prime} 31.4491^{\prime \prime} \mathrm{N}$ & 36.40 & 63.62 & 6.86 & 0.14 & 0.57 & Sandy Mud & -18.75 & 34.03 & 147.38 \\
\hline 50 & $101^{\circ} 23^{\prime} 26.1567^{\prime \prime} \mathrm{E}$ & $1^{\circ} 43^{\prime} 31.5240^{\prime \prime} \mathrm{N}$ & 34.25 & 65.75 & 7.08 & 0.10 & 0.44 & Sandy Mud & -19.16 & 34.46 & 145.49 \\
\hline
\end{tabular}




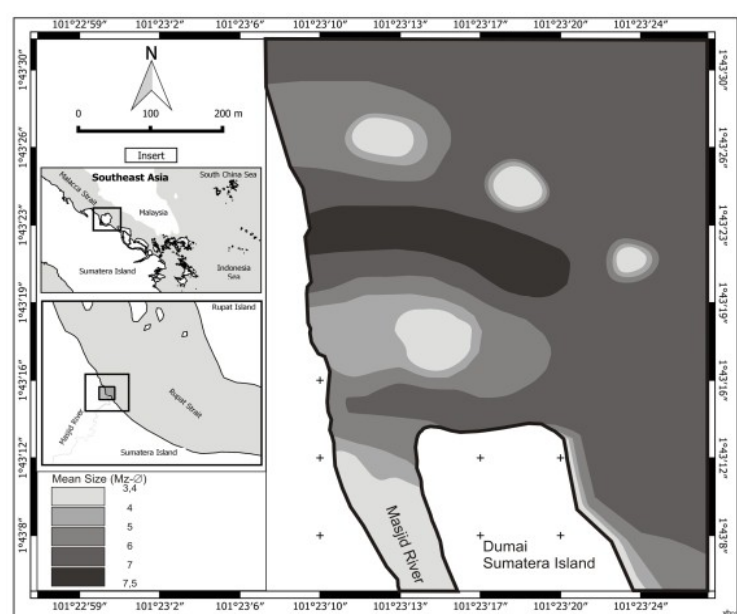

Figure 3. Geographical distribution of mean diameter $(\mathrm{Mz} \emptyset)$

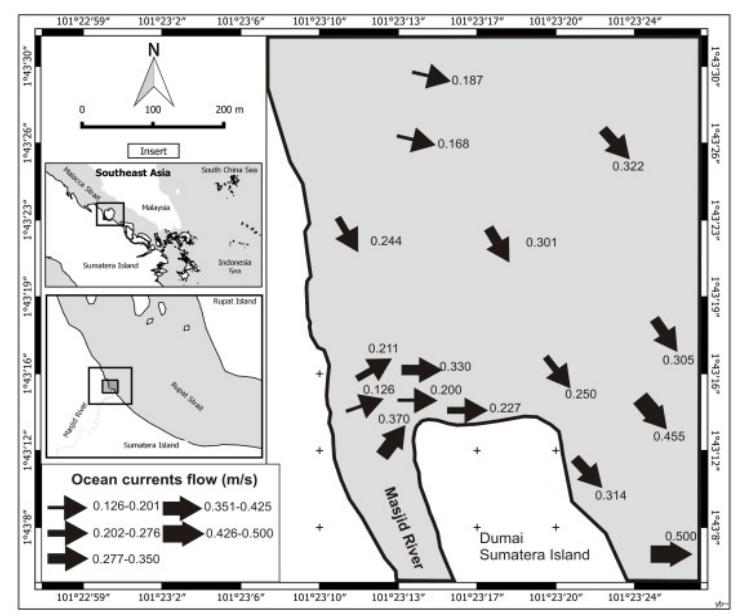

Figure 5. Velocity and direction of the high tide current

of mean diameter (Mzø) and mud content (\%) are shown in Figures 3 and 4, respectively.

The bottom sediments in the Mesjid River Estuary are characterized by very fine sand to very fine silt (Mz ø: 3.40-7.38 ø). Gravels are not found at all stations, which are occupied dominantly by mud fractions (more than $50 \%$ ), indicating that the bottom character in the estuary must be mud and sandy mud except for stations 7,12 , $13,15,39$ and 40 which are composed of muddy sand.

The areas with low mean diameter $(\mathrm{Mz} \varnothing: \leq 5 \varnothing)$ can bee seen in the river channel (Stn. 1 and 2) and in the area off the river mouth (Stn. 7, 12, 13 and 15). The peculiar features of these sediments are assumed to result from the derivation of coarser materials from the Mesjid River drainage area and from the neighboring coastal areas accessible to erosion seaward of the estuary. In addition to, bottom sediments with low mean diameter are distributed in the area off the river mouth which are situated at the boundary between different water masses, namely the fresh water mass and marine water mass. Strong main currents are seen in the area composed of coarser grained-sediments, indicating that strong tidal currents as rapid as more than $0.4 \mathrm{~m} / \mathrm{s}$

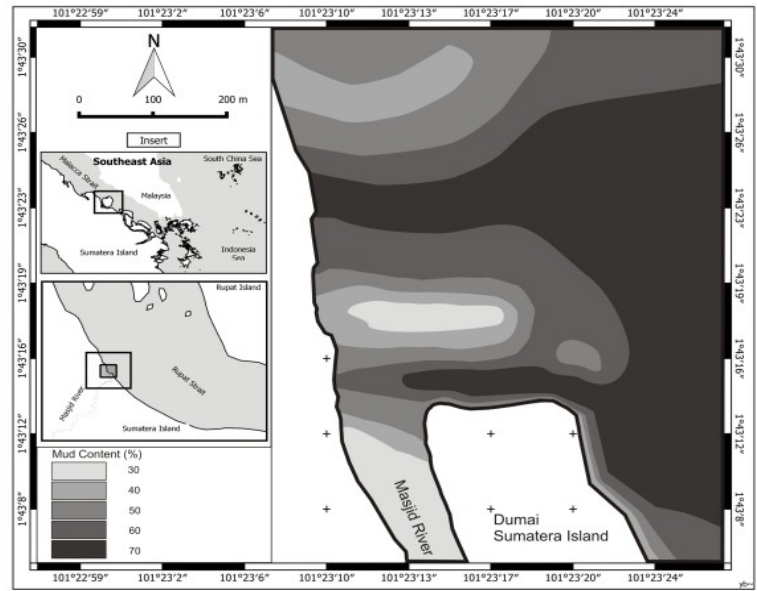

Figure 4. Geographical distribution of mud content (\%)

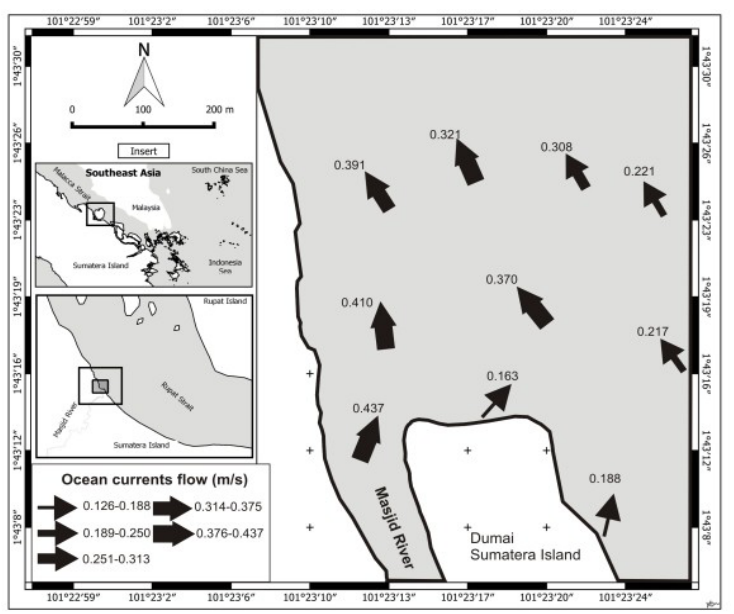

Figure 6. Velocity and direction of the ebb current

influence the bottom sediments. Other areas occupied by finer grained-sediments which are influenced by weak tidal currents less than $0.3 \mathrm{~m} / \mathrm{s}$ (Figures 5 and 6). Strong relationship between the distribution of median diameter of bottom surface sediments and currents system was also found in the Dumai Coastal Waters of Rupat Strait which located close to the Mesjid River Estuary [Rifardi et al., 2015] and in the strait which connected to the estuary [Rifardi and Syahrul, 2013], and this relationship is also recognized in the South Yatsushiro Sea, southwest Kyushu Japan [Rifardi et al., 1998]. The relationship between particle size and water velocity was also explained by Koiter et al. [2013]. Transport directions of sediments are mostly controlled by current circulation [Wei et al., 2004]. The seasonal variation of suspended sediment transport and its seasonal dispersal patterns from the Bohai Sea to the Yellow Sea was discussed by Wang et al. [2016] and the results indicate that the dispersal patterns of sediment were strongly influenced by current system.

The Mesjid River Estuary is occupied by high mud contents which is all the stations have mud contents more than 50\% with high mean diameter (Mzø : > 5ø) 


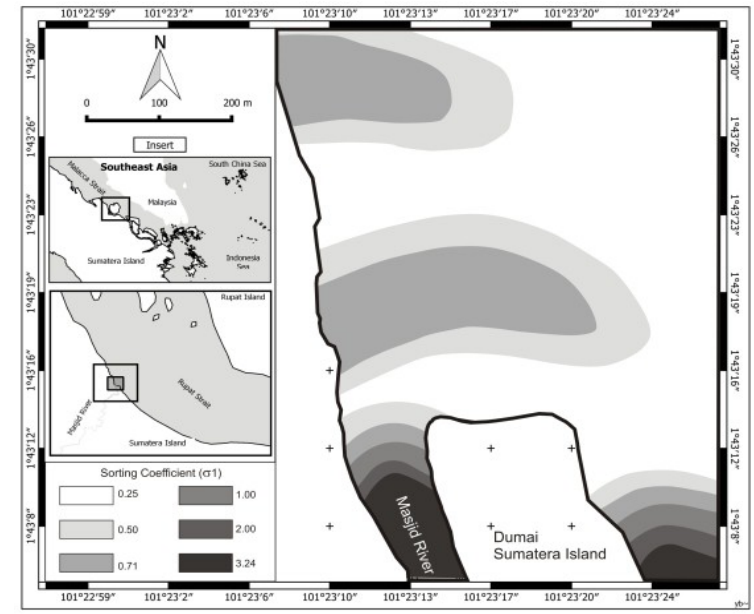

Figure 7. Distribution of the sorting coefficient $\left(\mathrm{O}_{\mathrm{i}}\right)$

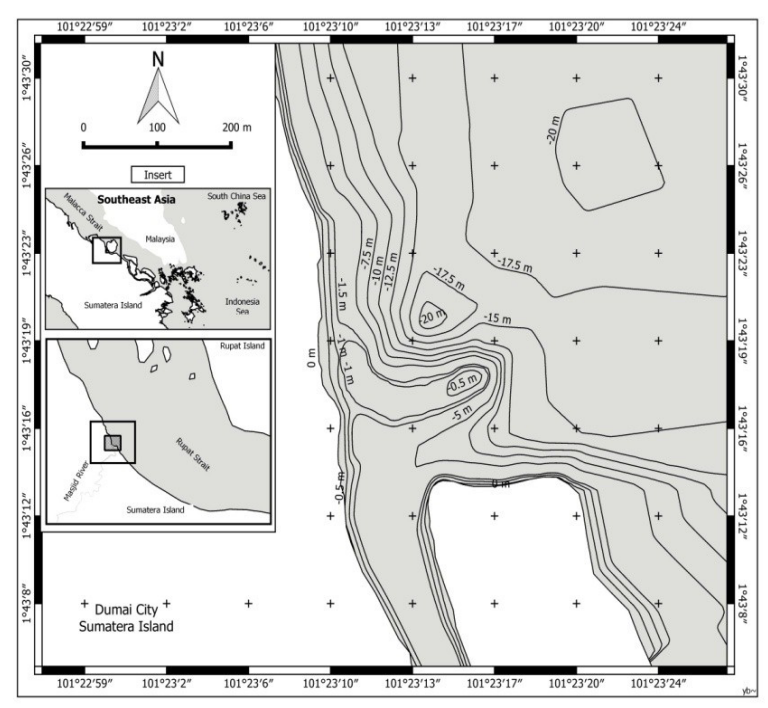

Figure 9. Bathymetric map of the study area

except for the stations located in the two areas (the river channel and the area off the river mouth). The river drainage areas are mainly composed by alluvial deposits, moreover the coastal area of the estuary is occupied by peat land. High mud contents in the estuary are supposed to be derived from the areas which are suffered by erosion and abrasion. The sediment loads were highly correlated to drainage area and river discharge, so larger basins usually had larger sediment loads [Gellis et al., 2007]. More variety of the distributions of mean diameter $(\mathrm{Mz} \varnothing)$ and of mud contents in the estuary indicate that the distributions strongly influenced by tidal currents system. Tidal currents flowing from Malacca Strait to the southeastward flow through the estuary during the high tide. The velocity of the high tide current coming into the estuary reaches $0.17-0.50 \mathrm{~m} / \mathrm{s}$. On the contrary, the velocity of the ebb current reaches $0.19-0.44 \mathrm{~m} / \mathrm{s}$ and the current flowing from Malacca Strait to the northwestward flow through the estuary.

The distributions of sorting coefficient $\left(\mathrm{O}_{\mathrm{i}}\right)$ and

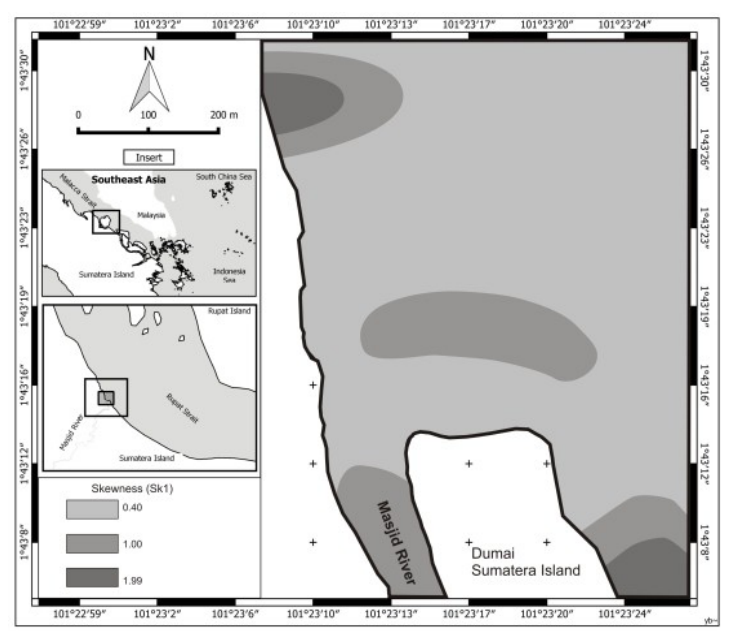

Figure 8. Distribution of the skewness $\left(\mathrm{Sk}_{\mathrm{i}}\right)$

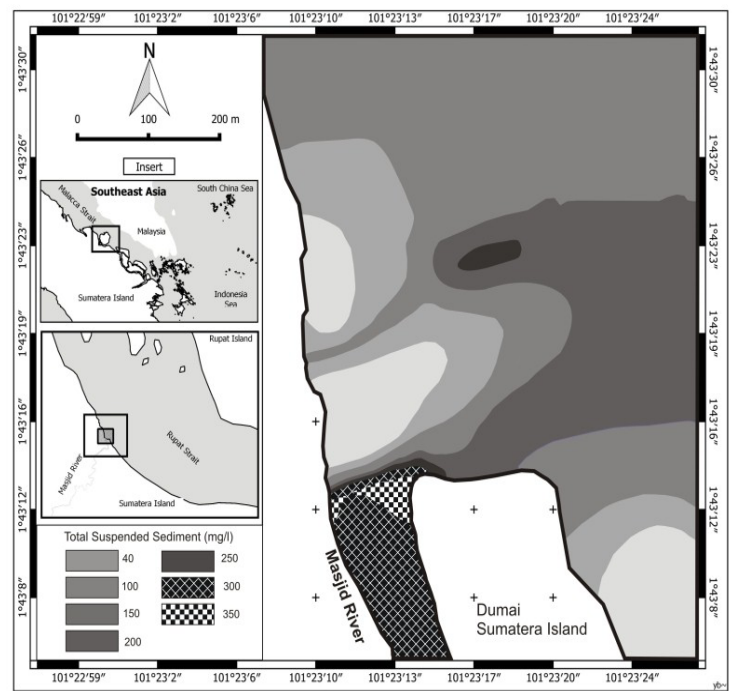

Figure 10. Distribution of suspended sediment

skewness $\left(\mathrm{Sk}_{\mathrm{i}}\right.$ ) are shown in Figure 7 and 8, respectively. A general trend of sorting coefficient in the studied area is that sediments are poorly sorted (0.1-0.9 ø) except for Station 1 showing high value as $3.69 \varnothing$.

Poorly sorted sediments (1-3 ø) are recognized in areas influenced by strong tidal currents $0.24-0.37$ $\mathrm{m} / \mathrm{s}$ at the high tide current and $0.37-0.44 \mathrm{~m} / \mathrm{s}$ at the ebb current) as seen in the river channel (Stn. 1 and 2 ), the area off the river mouth (belt like-area: Stn. $7,12-18)$ and the northern part of study area (Stn. $39,40,45$ and 46$)$. Well sorted sediments $(<0.5 \varnothing)$ is distributed in other areas of the estuary except the three areas aboved, and the areas are under the influence of weak tidal currents. Poorly sorted sediments indicating the Mesjid River Estuary is occupied by unstable tidal current system (Rifardi, 2015).

The distributions of skewness $\left(\mathrm{Sk}_{\mathrm{i}}\right)$ indicate that the study area is characterized by very fineskewed sediments $(>0.4)$. High skewed sediments are recognized in the river channel, the area off the 
Tabel 2. Results of accumulation rates of sediments and sedimentation rates

\begin{tabular}{lllll}
\hline Station & $\begin{array}{l}\text { Accumulation rates } \\
\left(\mathrm{gram} / \mathrm{m}^{2} / \text { day }\right)^{*}\end{array}$ & $\begin{array}{l}\text { Accumulation rates } \\
(\text { ton/ha/year })^{* *}\end{array}$ & $\begin{array}{l}\text { Accumulation rates } \\
\left(\mathrm{ml} / \mathrm{m}^{2} / \text { day }\right)^{*}\end{array}$ & $\begin{array}{l}\text { Sedimentation rates } \\
(\mathrm{m} / \text { year })^{* *}\end{array}$ \\
\hline 7 & 120.24 & 438.88 & 52.8 & 0.019 \\
12 & 122.4 & 446.76 & 57.6 & 0.021 \\
13 & 123.12 & 449.39 & 67.2 & 0.024 \\
15 & 186.48 & 680.65 & 81.6 & 0.029 \\
Average & 138.06 & 503.92 & 64.8 & 0.024 \\
\hline
\end{tabular}

Note: ${ }^{\star}$ actually counted

** converted

river mouth and the northern part of study area. Geographical distribution of the skewness sediments show the same tendency as of the sorting coefficient $\left(\mathrm{O}_{\mathrm{i}}\right)$, indicating the study area is strongly under the influence of tidal currents system as mentioned above.

The Mesjid River Estuary has a rather flat bottom topography less than $21 \mathrm{~m}$ deep and gets gradually deeper northeastwards except for the area off the river mouth. This area is recognized as "belt like area" having west-east direction in the Mesjid River Estuary showing less than $1.0 \mathrm{~m}$ deep and the area is the shallowest area characterized by muddy sand of the bottom character. The deepest parts are found in the central and northeastern parts of the study area, more than $20 \mathrm{~m}$ in deep (Figure 9).

The poorly sorted sediments supplied by the Mesjid River were deposited in the belt like area, but the deposition of mostly mud sediments was prevented by the high tide and ebb currents flow across the north and south parts. Judging from the distributions of mean diamater $(\mathrm{Mz} ø$ : Figure 3) and mud content (Figure 4 ), the mud parts of the sediments must have been transported from the mouth of the river by the currents toward the northeastern and eastern parts where the high suspended sediments are seen (Figure 10). The river thus acted as a major contributor of terrestrial sediment to the study area, as also found by Rifardi [2008], the river mouth area is dominantly influenced by fresh water run from the river. Gibbs and Bremner [2008] reported that estuary may periodically receive large amounts of terrigenous sediment from the whole catchment; and contributor of terrestrial sediment to global ocean, presenting significant influence on global material cycling and marine ecosystem Martin et al. [1993].

The distribution of suspended sediment concentration $(\mathrm{mg} / \mathrm{l})$ shows the study area is occupied dominantly by the high concentration more $100 \mathrm{mg} / \mathrm{l}$ except for 14 stations (Stn. 3, 4, 7, 8, 12, 13, 15, 16, 17, $21,22,27$ and 28) showing low concentration less than $70 \mathrm{mg} / \mathrm{l}$. The concentration of the area is higher than the concentration of normal marine waters condition i.e. maximum $20 \mathrm{mg} / \mathrm{l}$ which clearly indicate the suspended sediment discharged from other areas and transported to the study area by tidal currents system. The Mesjid River with rather large drainage areas, discharge the highest suspended sediment $(354.61 \mathrm{mg} / \mathrm{l})$ into the study area. It became clear when low salinity (10-12 $\%$ ) observed at Stations 1 and 2 (the river channel area) due to the influence of fresh water. The suspended sediment is also transported together with marine water masss by tidal currents system derived from northern and eastern parts and deposited into the study area. The lowest concentrations $(<53 \mathrm{mg} / \mathrm{l})$ are found in the stations $7,12,13$ and 15 which are located in the belt like area under brackish condition i.e. nearly 20 $\%$ in salinity affected more or less by fresh water. The similarity today between the river input and the tidal fine sediments, analysed from the inner tidal limit to the suspended sediment front present in the outer Estuary and inner Bristol Channel [Kirby and Parker, 1982], points to the river catchments as overwhelming source of the fine material. A prodelta began forming just after highstanding under slow sea-level rise, and the delta front arrived by voluminous sediment input from the Nakdong River, Korea [Cho et al., 2016].

The concentrations of suspended sediment measured during the ebb tide at station 2 in three different depths (surface: $335.96 \mathrm{mg} / \mathrm{l}$, middle: 350.92 $\mathrm{mg} / \mathrm{l}$ and bottom: $376.95 \mathrm{mg} / \mathrm{l}$ ) show high value 354.61 $\mathrm{mg} / \mathrm{l}$ in average. This station is characterized by 2.3 $\mathrm{m}$ depth $52.6 \mathrm{~m}$ width and current velocity reaches $0.25 \mathrm{~m} / \mathrm{s}$. Based on the characteristics, the water discharge flowing through the station enter the Mesjid River Estuary reaches $30.24 \mathrm{~m} 3 / \mathrm{s}$. Total amount of lithogeneous sediments (ton/year) discharged by the Mesjid River into the estuary was calculated based on the suspended sediment concentration $(\mathrm{mg} / \mathrm{l})$ and the water discharge $(\mathrm{m} 3 / \mathrm{s})$. The results of the calculation show that the lithogeneous sediments were discharged by the Mesjid River into the estuary reach 926 ton/ day which is equal to 338,173 ton/year. The sediments were derived from the river's hinterland due to the land development [Putra et al., 2017]. In addition, ebb currents play their own role in the transport of sediment, but this is primarily through lateral erosion associated with channel migration [Oyedotun, 2016]

The stations 7, 12, 13 and 15 were used as locations to trap the suspended sediment using sediment traps to determine sediment accumulation during the ebb tide. The results of accumulation rates of the 
sediments in the stations which are located at the area off the river mouth "the belt-like area" having east-west direction in the Mesjid River Estuary shown in Table 2.

The lithogeneous sediments are accumulated into the area as much as 503.92 ton/ha/year and are deposited (sedimentation rates) $0.024 \mathrm{~m} /$ year. The area is characterized by muddy sand of the bottom characters and by coarser grained-sediments $(\mathrm{Mz} ø$ : 3-5 ø: very fine sand to coarse silt), and the area has become the shallowest (0.5-1.0 meters in depth) area which is supposed a new sandbar in the Mesjid River Estuary. The development of the active delta lobe was a product of riverine sediment supply, channel geometry and estuarine hydrodynamics [Xing et al., 2016]. The area is assumed as the confluence area between fresh water mass derived from the Mesjid River and marine water mass. Velocities of the flood and ebb currents are relatively strong in this area. However, bottom currents in the area must be very weak in spite of the strong surface tidal currents. Suspended sediments are suggested to be supplied by the ebb current flows northward from the South Mesjid River Estuary where a great amount of sediment derived from the hinterland through the Mesjid River, has been deposited in the area. This assumption is supported by the high sedimentation rates as well as high accumulation rates of sediments in the area

The high sedimentation rates in the area can also be explained by the occurence of a current rip between the fresh water mass and the marine water mass entering into the estuary, and quick sedimentation of the suspended sediments composed by silt materials which flocculated in the sea water. This peculiar feature was also seen in the continental shelf adjancent to Japan as reported by and Sakamoto [1982]. The feature is also found in Parangtritis beach as mentioned by Retnowati et al. [2012] shoreline morphology are considered as signatures of rip currents occurrence along Parangtritis beach.

Total amount of lithogeneous sediments (ton/ year) discharged by the Mesjid River into the estuary reach 926 ton/day which is equal to 338,173 ton/year. Some of the sediments are deposited in the area off the river mouth "belt like area" which showing the high sedimentation rates $(0.024 \mathrm{~m} /$ year $)$ and the area is the shallowest part in the estuary (Figure 9). The depth of the area ranges from 0.5 to $1.0 \mathrm{~m}$ and the area is assumed as a sandbar which supposed to be sandbank in 20 years later if the sediments discharge and the currents system show the same situation as the present. Sedimentation history of sanbars in flood-tidal delta in Lake Tofutsu, Japan indicate that even though the sandbars appeared to comprise the same sand material, the sediment under the sandbars had a very varied stratigraphy, comprising the river-bone muddy sediment derived from the upstream side [Watanabe and Sassa, 2016].

\section{Conclusion}

The major contributing factor for formation of sandbar in the Mesjid River Estuary is the amount of lithogeneous sediment discharged by the Mesjid River, although the estuary also receive small amount of the sediment from other areas. The fresh water mass contained the lithogeneous sediment derived from the Mesjid River is confluent to marine water mass contained suspended sediment in the area off the river mouth which recognized as "belt like area" and coarser grains of the sediments are deposited in the area. The occurrence of a current rip between the fresh water mass and the marine water mass entering into the estuary, and quick sedimentation of the suspended sediments in the belt like area. The lithogeneous sediments are accumulated in the area up to 503.92 ton/ha/year cause of high sedimentation rates $(0.024 \mathrm{~m} /$ year $)$ and the area is assumed as a sandbar as shown by the shallowest of bathymetry $0.5-1.0 \mathrm{~m}$ depth. The sandbar is supposed to be sandbank in 20 to 40 years later if the sediments discharge and the currents system show the same situation as the present. The suspended sediment discharged by the river into the estuary during the ebb tide which assumed as the total amount of lithogeneous sediments entering the estuary. The concentrations of suspended sediment discharged by the river reach $354.61 \mathrm{mg} / \mathrm{l}$ which is equal to 338,173 ton/year of the lithogeneous sediments. The tidal currents play important role on the distribution the sediments. The lithogeneous sediments discharged by the Mesjid River and suspended sediment of marine water mass are transported toward the north into the Mesjid River Estuary during the ebb tide, and reversed during high tide. More variety of the distributions of mean diameter (Mzø) and of mud contents in the estuary suggest that the distributions strongly influenced by tidal currents system. The general feature of the bottom sediments is quite harmonize well with tidal currents system.

\section{Acknowledgement}

We express our deep gratitude to the Research Institute of Riau University, Minister of Education and Culture of Indonesia with contract number: 1001a/UN.19.5.1.3/LT/2015, for funding the present study. Particular thanks are due to $\mathrm{Mr}$ Yogi Novri Yusda, my undergraduate student, for his technical assistance in the field and laboratory works; all my colleagues at the Department of Marine Sciences, Riau University, for their kind help.

\section{References}

Alkhatib M., T. C. Jennerjahn and S. Joko (2007). Biogeochemistry of the Dumai River estuary, Sumatra, Indonesia, a tropical black-water river, Limnology and Oceanography, 52, doi: 10.4319/lo.2007.52.6.2410.

Amin, B., A. Ismail, A, Arshad, C. K. Yap and M.S. Kamarudin (2007). Distribution and speciation of heavy metals (Cd, $\mathrm{Cu}$ and $\mathrm{Ni}$ ) in coastal sediments of Dumai Sumatera, 
Indonesia, Coastal Development, 10(2), 97-113.

Amin, B., A. Ismail, A, Arshad, C. K. Yap and M.S. Kamarudin (2008), Anthropogenic impacts on heavy metal concentrations in the coastal sediments of Dumai, Indonesia, Environmental Monitoring and Assessment, 148(1), 291-305, doi:10.1007/s10661-008-0159-z.

Amin, B., A. Ismail, A, Arshad, C. K. Yap and M.S. Kamarudin (2009). Gastropod assemblages as indicators of sediment metal contamination in mangroves of Dumai, Sumatra, Indonesia, Water, Air and Soil Pollution, 201, 9-18.

Badrun, Y. (2008). Analisis kualitas perairan Selat Rupat sekitar aktivitas industri minyak bumi Kota Dumai, Jurnal Environmental Science, 1(2):17-25.

Cho, A., D. Cheong, J. C. Kim, S. Shin, Y. H. Park and K. Katshuki (2016). Delta formation in Nakdong River, Korea, during the holocene as inferred from the diatom assemblage, Coastal Reseach, 33(1): 67-77.

Gebert, J., B. Conlin, J. Cushing, S. Douglas and G.Westfall (2013). Sediment Quantity And Dynamics. Delaware Estuary Regional Sediment Management Plan (White Paper), U.S. Army Corps of Engineers, New Jersey Department of Transportation, U.S. Dept of Agriculture, Natural Resources Conservation Service, Waikato Regional Council.

Gellis, A. C., C. R. Hupp, J. M. Landwehr and M. J. Pavich, (2007). Sources and transport of sediment in the wransport of sediment in the watershed, p. 28, Synthesis of U.S. Geological Survey Science for the Chesapeake Bay Ecosystem and Implications for Environmental Management. U.S. Geological Survey, Reston, Virginia.

Gibbs, M. And D. Bremner (2008). Wharekawa Estuary SedimentSources, Environment WaikatoTechnicalReport 2008/07, 36 p., Environment Waikato, Hamilton East.

Kirby, R. and W. R. Parker (1982). A suspended sediment front in the Severn Estuary, Nature, 295, 396-399.

Koiter, A. J., P. N. Owens, E. L. Petticrew and D.A. Lobb (2013). The behavioural characteristics of sediment properties and their implications for sediment fingerprinting as an approach for identifying sediment sources in river basins, Earth-Science Reviews 125, 24-42.

Martin, J. M., J. Zhang, M. C. Shi, and Q. Zhou (1993).Actual flux of the Huanghe ( Yellow River) sediment to the western Pacific Ocean, Netherlands Journal of Sea Research, 31(3), 243-254.

Merian, R. D., Mubarak and S. Sutikno (2016). Analisis kualitas perairan muara Sungai Dumai ditinjau dari sspek fisika, kimia dan biologi, Dinamika Lingkungan Indonesia, 3(2):107-112.

Musrifin (2011). Mapping of Depth and Tidal Current System in Mesjid River Estuary, Dumai City, Berkala Perikanan Terubuk, 39(1), 44-50.

Nedi, S., B. Pramudya, E. Riani and Manuwoto (2010). Environmental characteristics of Rupat Strait, Environmental Science, 1(4), 25-35.

Oyedotun, T. D. T. (2016). Sediment characterisation in an estuary-beach system, J. Coast Zone Manag, 19: 433, doi: 10.4172/2473-3350.1000433.

Potter, I .C., B. M. Chuwen, S. D. Hoeksema and M. Elliott (2010). The concept of an estuary: A definition that incorporates systems which can become closed to the ocean and hypersaline, Estuarine, Coastal and Shelf Science, 87(3), 497-500.

Purba, N. P. and A.M.A. Khan (2010). Physical and chemical characteristics of Dumai Coastal Waters, Akuatika, 1(1), 69-83.
Putra, R. M., Rifardi and Elizal (2017). Kapasitas asimilasi total suspended solid (TSS) di muara Sungai Nerbit besar Kelurahan Lubuk Gaung Kecamatan Sembilan Kota Dumai Provinsi Riau, Terubuk, 45(1), In press. Retnowati, A., M. A. Marfai and J. T. S. Sumantyo (2012), Rip currents signatures zone detection on Alos Palsar Image at Parangtritis beach, Indonesia, Indonesian Journal of Geography, 43(2), 12-27.

Rifardi, K. Oki and T. Tomiyasu (1998). Sedimentary environments based on textures surface sediments and sedimentation rates in the South Yatsushiro Kai (Sea), Southwest Kyushu, Japan, Sedimentology Sociaty Japan, 48, 67-84.

Rifardi (2001). Study on sedimentology from the Mesjid River Estuary and its Environs in the Rupat Strait, the East Coast of Sumatera Island, Coastal Development, 4(2), 87-97.

Rifardi (2008). Analisis ekologi foraminifera bentik pada permukaan sedimen perairan Muara Sungai Mesjid dan Selat Rupat pantai timur Sumatera, Ilmu Kelautan, 13(2), 95-102. Rifardi (2012). Ekologi sediment laut modern, 167 p, UR Press, Pekanbaru, Indonesia.

Rifardi and Syahrul (2013). Analisis degradasi perairan Selat Rupat pantai timur Sumatera berdasarkan aspek sedimentasi sebagai dasar dalam perencanaan pembangunan dan pengelolaan wilayah pesisir Kota Dumai Provinsi Riau, 36 p., Laporan penelitian guru besar, Lembaga Penelitian dan Pengabdian Kepada Masyarakat, Universitas Riau, Pekanbaru Rifardi, Syahminan, Suwarni, R. B. Butar and N. Fidiatur (2015). Sedimentary environments of the Dumai Coastal Waters on the East Coast of Central Sumatera Island, Indonesia, ASM Science Journal, 9(2), 9-16.

Rifardi (2015). Studi karakteristik sedimen estuaria Sungai Dumai dan estuaria Sungai Mesjid Selat Rupat, 71 p., Laporan penelitian guru besar, Lembaga Penelitian dan Pengabdian Kepada Masyarakat, Universitas Riau, Pekanbaru

Sakamoto, W. (1982). Detritus-roles of suspended and bottom sediment on coastal marine ecosystem, Marine Sci. Monhtly, 14(8), 482-489.

Syahminan, E. Riani, S. Anwar and Rifardi (2015). Heavy metals pollution status $\mathrm{Pb}$ and $\mathrm{Cd}$ in sediments in Dumai Sea western waters-Riau Province, Pengelolaan Sumberdaya Alam dan Lingkungan, 5(2), 133-140, doi: 10.19081/jpsl.5.2.133.

Wang, A., H. Wang, N. Bi and X. Wu (2016). Sediment transport and dispersal pattern from the Bohai Sea to the Yellow Sea, Coastal Reaseach, 74, 104-116.

Watanabe, Y and S. Sassa (2016). Sedimentation history of sanbars in flood-tidal delta evaluated by seismic method in Lake Tofutsu, Japan, Coastal Research, 32(6), 1389-1401.

Wei, H., D. Hainbucher, T. Pohlmann, S. Feng and J.Suendermann (2004). Tidal induced Lagrangian and Eulerian mean circulation in the Bohai Sea, Marine Systems, 44(34), 141-151.

Wöstmann, R. and G. Liebezeit (2012). Geochemical evidence for different peat sources in the Siak estuary and along the east coast of Sumatra, Indonesia, Mires and Peat, 10(2), 1-13, http://www.mires-and-peat.net/.

Xing, G., H. Wang, Z. Yang and N.Bi (2016). Spatial and temporal variation in erosion and accumulation of the subaqueous Yellow River Delta (1976-2004), Coastal Research, SI, 74, 32-47. 